- Matthew Bacchetta, MD, New York, New York

- Clifford W. Barlow, MD, Southampton, United Kingdom

- Emre Belli, MD, Le Plessis-Robinson, France

- Mark F. Berry, MD, Durham, North Carolina

Jay K. Bhama, MD, Pittsburgh, Pennsylvania

Shanda H. Blackmon, MD, Houston, Texas

Joanna Chikwe, MD, New York, New York

Ufuk Demirkilic, MD, Ankara, Turkey

Jessica S. Donington, MD, New York, New York

Alessandro Giamberti, MD, San Donato Milanese, Italy

Peter J. Gruber, MD, Salt Lake City, Utah

T. Sloane Guy, MD, Philadelphia, Pennsylvania

Michael E. Halkos, MD, Atlanta, Georgia

Jianxing He, MD, Guangzhou, China

David P. Jenkins, MD, Cambridge, United Kingdom

Sunjay Kaushal, MD, Baltimore, Maryland

Minoo N. Kavarana, MD, Charleston, South Carolina

Bob Kiaii, MD, Arva, ON, Canada

Anthony W. Kim, MD, New Haven, Connecticut

Young T. Kim, MD, Seoul, Republic of Korea

Charles T. Klodell, MD, Gainesville, Florida

Christoph Knosalla, MD, Berlin, Germany

Christopher J. Knott-Craig, MD, Memphis, Tennessee

John R. Liddicoat, MD, Mounds View, Minnesota

Andrew J. Lodge, MD, Durham, North Carolina

S. Chris Malaisrie, MD, Chicago, Illinois

Joseph T. McGinn, MD, Staten Island, New York

Michael E. Mitchell, MD, Milwaukee, Wisconsin

T. Brett Reece, MD, Aurora, Colorado

Nabil Rizk, MD, New York, New York

Gu Tianxiang, MD, Shenyang, China

Alper Toker, MD, Istanbul, Turkey

Ching Tzao, MD, Taipei, Taiwan

Thomas J. Watson, MD, Rochester, New York

Dennis A. Wigle, MD, Rochester, Minnesota

Please make plans to attend AATS Week 2015, beginning with the Mitral Conclave in New York City on April 23-24 and followed by the 95th Annual Meeting of the American Association for Thoracic Surgery in Seattle, WA, on April 25-29.

\section{The AATS Welcomes You to Submit Your Abstract and Videos for AATS Week 2015}

\section{Mitral Conclave}

\section{Program Director:}

David H. Adams

Program Committee:

Anelechi C. Anyanwu

Tirone E. David
Pedro J. del Nido

Gilles D. Dreyfus

Volkmar Falk

Rakesh M. Suri

Hugo K.I. Vanermen

Francis C. Wells

Abstract/Video Deadline: Sunday, January 4, 2015, by 11:59 PM Eastern Standard Time.

\section{Submission of Abstracts and Case Videos}

The AATS welcomes you to submit your Abstracts and Videos to the MITRAL CONCLAVE 2015. Specific instructions for abstract and video submission are located on the Web site at www.aats.org/mitral.

Accepting Abstracts and Videos in the following categories:

- Degenerative Valve Disease

- Mitral Regurgitation in Heart Failure

- Ischemic Mitral Regurgitation

- Rheumatic Mitral Valve Disease

- Mitral Valve Endocarditis

- Congenital Mitral Valve Disease

- Other Mitral Valve Disease

- Mitral Repair Techniques \& Strategies

- Mitral Valve Replacement

- Long-Term Outcomes

- Atrial Fibrillation in Mitral Valve Disease

- Tricuspid Valve Diseases

- Tricuspid Valve Repair

- Mitral \& Tricuspid Valve Reoperations

- Mitral Annular Calcification, Abscess, or Disruption

- Imaging of Mitral Valve Disease

- Challenging Clinical Cases

- Minimally Invasive \& Robotic Mitral Valve Repair

- Transcatheter Mitral Valve Therapies

- Mitral Valve Modeling

- From Bench to Bedside: Mitral Valve Research

95th Annual Meeting

Abstract \& Case Video Submission Deadline:

Tuesday, October 14, 2014, at 11:59 PM Eastern Daylight Time.

Submission of Abstracts and Case Videos

The AATS welcomes you to submit your Abstracts and Case Videos to the 95th ANNUAL MEETING. Specific instructions for abstract and video submission are located on the Web site at www.aats.org/annualmeeting.

\section{Presentation Types include:}

- Regular Session (Plenary and Simultaneous Sessions)

- Laboratory Research Fora (Cardiac Surgery and General Thoracic Surgery)

- Emerging Technologies and Techniques Forum

- C. Walton Lillehei Resident Forum 
- Case Videos (for display in the AATS Learning Center located in the Exhibit Hall)

Plenary and Simultaneous Session Abstracts may be submitted for the following categories:

- Adult Cardiac

- Congenital

- General Thoracic

- Perioperative Care

Case Videos may be submitted for the following categories:

- Adult Cardiac

- Congenital

- General Thoracic

Waiver of mandatory manuscript submission for publication in JTCVS may be requested at the time of submission.

The AATS is also accepting abstracts for the Allied Health Poster Competition until January 6, 2015. More details can be found at www.aats.org/annualmeeting.

\section{AATS Clinical Trials Methods Course}

October 23-25, 2014

Hyatt Regency O'Hare, Chicago, IL

The AATS is pleased to announce its inaugural AATS Clinical Trials Methods Course co-chaired by Drs David H. Harpole and Marco Zenati, October 23-25, 2014. With the continually evolving nature of clinical trials, the course will provide an intensive and interactive training program for 40 cardiothoracic surgeons across all subspecialties to acquire the critical skills and better understand the essential steps in effective clinical trial design and implementation.

The 2-and-a-half-day program will include an expert faculty of both cardiothoracic surgeons and biostatisticians who will mix didactic lectures with hands-on breakout sessions to help address the challenges in translation from "bench" to clinical protocols and level-A comparative effectiveness clinical research.

For more information and to secure your registration or housing, please visit the AATS Web site (www.aats.org).

\section{AATS Focus on Thoracic Surgery: Novel Technologies in Lung Cancer}

November 21-22, 2014

Renaissance Boston Waterfront Hotel

Boston, MA

Lung cancer is the second most common malignancy in the Western world and the most common cause of cancer-related death. Recent innovations in diagnosis, staging, and management of early stage and locally advanced non-small cell lung cancer have changed the paradigm for surgical management of lung cancer patients. A virtual explosion of technological development has enabled widespread use of minimally invasive approaches that current and future thoracic surgeons must embrace to improve the care of patients with lung cancer.

Join us in Boston once again as the AATS highlights these recent developments in its 2014 "Focus on Thoracic Surgery" program, which will focus on Novel Technologies in Lung Cancer. The faculty includes internationally recognized experts in lung cancer and application of new technology for its surgical management. We look forward to seeing you in Boston!

\section{PROGRAM COMMITTEE MEMBERS}

G. Alec Patterson, Program Director

Washington University School of Medicine

David J. Sugarbaker, Program Director

Baylor College of Medicine

Thomas A. D'Amico

Duke University Medical Center

Shaf Keshavjee

University of Toronto

James D. Luketich

University of Pittsburgh Medical Center

Bryan F. Meyers

Washington University School of Medicine

Scott J. Swanson

Brigham and Women's Hospital/Harvard Medical School

Dana Farber Cancer Institute

Course Highlights:

- Imaging and Staging

- Surgical Alternatives

- Simulation, Education, and Training

- Optimal Management of Lung Metastases

- Credentialing/Efficiencies

- Intraoperative Management

- Advanced Minimally Invasive Techniques

For more details and to register, please visit: http://aats.org/ lungcancer.

\section{AATS Grant Writing Workshop}

March 6, 2015, Bethesda, MD

Organized by the AATS Scientific Affairs and Government Relations Committee, the 2015 AATS Grant Writing Workshop will take place on Friday, March 6, 2015, at the Doubletree Bethesda in Bethesda, MD (9 miles from 